DOI: $10.33067 /$ SE.1.2021.7

Driton Kuqi

\title{
Constitutional - Legal Engineering of the Model of Democracy in North Macedonia
}

\begin{abstract}
This thesis is a critical analysis of the constitutional and legal order of the Republic of North Macedonia, following the chronological process dating from the gaining of the county's independence, through the armed conflict in 2001 that brought constitutional changes, to today. The first decade after the breakup of Yugoslavia was crucial for the North Macedonian state and its citizens. The writing/creation of the constitution of the new, independent state was not an easy process and it did not pass peacefully nor did it pass without any problems. The complex social process and relations have initiated the need for amendments to the Constitution, which, since its adoption in 1991 until today, has been changed 32 times in order to adapt to new, emerging situations and to give constitutional and legal responses to the inherent challenges. Of course, proper changes also occurred in the political system itself as a result of numerous factors, which have more or less influenced its character and shape.
\end{abstract}

Keywords: Democracy, Consociational Democracy, Constitutional Order

\section{Introduction}

From the moment independence was secured, the electoral model in the Republic of Macedonia, as an important element of the electoral system in the wider sense of the word, has undergone numerous transformations; from a majority principle election model in two rounds, to a proportional representation with closed lists. In the first parliamentary elections in 1990 and the second in 1994, the allocation of mandates was carried out by applying the majority principle election model in two rounds,

^ Driton Kuqi - University of Tetova, e-mail: driton.kuci@unite.edu.mk, ORCID: 0000-0002-0938-1263. 
within unanimous electoral units. The Law on the Election of Members of Parliament in the Parliament of the Republic of Macedonia since 1998 has abandoned the majority electoral model and replaced it with the combined (mixed) electoral model, according to which 85 seats were allocated on the basis of the majority electoral model with a relative majority, and $35 \mathrm{MP}$ seats, on the proportional model. In the 2001 elections held after the armed conflict and after the adoption of the Framework Agreement and the constitutional amendments (as well as all subsequent elections) the proportional election model was applied. Today, according to the decisions in the Electoral Code adopted in 2006 and amended several times since then, a proportional electoral model is applied within six constituencies in which twenty deputies and three constituencies in the Diaspora are elected, from which three MPs can be elected.

The process of building the Macedonian state went through two different phases, which had something in common: the transition to democracy and democratic consolidation. In the first period, the Republic of Macedonia was oriented towards western liberal democracy, building a political system dominated by the elements and characteristics of the majority democracy. Of course, the first multi-party elections were preceded by a legal framework that guaranteed the freedom of political association, i.e., the formation of political parties as a necessary presumption for competitive elections. In the 1991 Constitution, political pluralism and free, direct, and democratic elections were one of the eleven fundamental values of the constitutional order of the Republic of Macedonia. ${ }^{1}$

From 2001 to the present, in the conditions of a post-conflict environment, the political system was moving towards the so-called, power sharing model, with strong elements of the "Liphart Concept" for consociational democracy.

\section{About Democracy}

Democracy belongs to the ranks of the great politically-legal, ethicallyphilosophical and sociological phenomena that have always attracted the attention of scientists from almost all socially humanitarian areas. ${ }^{2}$ The term 'democracy' is one of the most widely used concepts in both political science and everyday life, and is also a target. The use of this term leads to a great deal of confusion, since it tends to contort when trying to define

1 Article 8, paragraph 1, line 5 of the Constitution of the Republic of Macedonia from 1991.

2 D. Bajaldziev, Introduction to Law, Skopje 2009, p. 122. 
it. ${ }^{3}$ It is therefore no coincidence that in determining this concept there is almost always a striving for a specific definition or a certain characteristic that, as a whole, completes its meaning. Most simply defined as "rule by the people," this form of social order has been subject to different, wideranging definitions. Starting from a "bad and undesirable form of government," which is what Greek philosophers Plato ${ }^{4}$ and Aristotle ${ }^{5}$ considered it to be, through Jean Jacques Rousseau ${ }^{6}$ and Montesquieu's ${ }^{7}$ concept that democracy is "a common good," we come to today's "era of democracy" for which speaks the fact that from 195 states, 125 declare themselves as democracies. ${ }^{8}$

During its more than 2,500-year history, democracy has been constantly renewed and developed through various models of institutional implementation. Democracy is not invented at in one fell swoop, like a steam engine, but it has been created multiple times and in different societies. ${ }^{9}$ But the widespread acceptance of democracy as an appropriate form of organisation of political life is one hundred and fifty years old. Namely, the term "democracy" in its modern sense began to be used in the nineteenth century, signifying a system of representative democracy in which representatives were elected to fair and free elections. Historically, and through a wide variety of differences, today we can conclude that modern democracy rests on several values: participation as a broader concept that not only has strong political implications, but also that of the social and economic; majority rule and minority rights, which points to the fact that while democracy is by definition the rule of the majority, it must also take

${ }^{3}$ S. Klimovski, T. Karakamisheva, R. Desoska, Political System, Skopje 2010, p. 119.

4 Plato had criticises democracy in his dialogue "Republic", wherein he says that democracy comes about when the poor majority will overthrow the wealthy minority, as an anarchic, colourful state order, when they share equality in all, regardless of both equals and the unequal. Because of this, he wrote, democracy is a bad form of government and is the backbone of tyranny as the worst possible form of state order.

5 Aristotle had a similar view of democracy as Plato, the difference being that, according to him, democracy can be a good form of ruling, but only if there is rule of law.

${ }^{6}$ Rousseau believed that the basic principles of democracy are freedom and equality. In each community, the government should be in line with the people, and such a pact is an act of sovereignty that should lead to the common good.

7 Montesquieu argued for a division and balance between the executive, the legislature and the judiciary, as a means of guaranteeing the freedom of the individual. This doctrine, later, would be the foundation for the creation of the US Constitution, with the division of power between the president, the Congress, and the judiciary.

${ }^{8}$ Freedom In The World 2015, Discarding Democracy: Return to the Iron Fist, p. 8

9 R. Dahl, On Democracy, London 1998, p. 8. 
into account the rights of minority groups; the rule of law and fair trial, which ensures an autonomous legal order and a restriction of the powers of public authorities and the provision of fair access to an independent and fair judiciary; a commitment to human rights, whose respect, protection and fulfilment must be secured by a democratic state; political pluralism that can provide sufficiently flexible structures to adapt to changes but which still remain a stable basis for democratic governance; free and fair elections as the most basic and unique characteristic of democracy, through which every citizen can express their will for change, i.e., compliance with current policies and participating in the ongoing process of assessment; and the separation of powers between legislative, executive and judicial bodies that function independently, but who have responsibility towards each other and the people.

As a system of government, democracy is still the target of much criticism to this day. Most of it moves in the same direction - not all citizens can be equally educated and informed about political life in a country, so it would not be beneficial for them to make important decisions. One of the disadvantages is connected with the achievement of equality, the possibility of self-destruction as a result of its openness, as well as the problem with the majority government. More precisely, this pertains to whether there are certain limits that the majority cannot overstep and rights that it cannot take away from the minority by outvoting. The Italian philosophers Wilfredo Pareto and Gaetano Mosca, however, claim that democracy is just one facade that serves the political elites to mask reality.

However, the weaknesses of democracy are incomparably smaller than those of an undemocratic system of government, which gives it a huge advantage over others because democracy is, above all, a system over which the citizens have control. Former British Prime Minister Winston Churchill was and is known for making the following memorable quip (among others) on democracy: "Democracy is the worst form of government, except for all the others." This well-known quote brings us to an important conclusion: the perfect democracy does not exist, but in spite of that, it is the most successful system of government.

Behaviour in accordance with the opinion of the majority, however, is not a central point of interest for the pluralist democracy. Namely, according to this model, democracy exists when many organisations acting separately from the government put pressure on democracy, confronting it with its own interests and causing its reaction. ${ }^{10}$ Unlike the majority

10 R. Dahl, Dilemmas of Pluralist Democracy, New Haven 1982, p. 5. 
model, according to the supporters of pluralist democracy, ${ }^{11}$ instead of a centre of sovereign power, it is necessary to have more power centre, none of which are and cannot be sovereign. The pluralist model seeks to limit the actions of the majority, so that interest groups come to the fore. According to US political scientist Dahl, this is a model where decisionmaking does not come from a single political centre that is in the role of a monopoly, but such power is distributed both vertically and horizontally at a number of different levels of decision-making. What ensures the proper functioning of this model is the consensus for basic liberal values in political life. On the other hand, the majoritarian democracy is based on electoral mechanisms that turn the power of the majority into the ability to make political decisions. In this model of democracy, the wider public (rather than interest groups) control the actions of the government.

The key principle of organising the rule of democratic systems is the division of power into the legislative, executive and judicial. The consistency with which the government is divided, as well as the forms of their mutual control and cooperation, offers an answer to the question of what kind of institutional model of the political system is concerned. The relationship between legislative and executive power is essential for any political system. This relationship is not only determined by the constitutional position of institutions, but also by political and other external factors. The constitution of a state is one that determines the horizontal relation between the legislature and the executive power, its powers and duties, as well as any possibilities for mutual influence.

When one system is said to be based on the principle of the separation of power, it means that the relations among the holders of state power are characterised by organisational and functional independence. ${ }^{12}$ All forms of state power organisation occurred via an empirical procedure. In time, the parliamentary system in England was shaped, followed by the presidential system in the United States, while the parliamentary system had its first constitutional presence in Switzerland. Over time, there was some convergence of the systems to their approximation which resulted in mixed systems. ${ }^{13}$

The presidential system is a system of government based on the principle of a strict separation of state power and the principle of "checks

11 Although many scientists have, however, contributed to this model, pluralist democracy is most closely identified with political scientist Robert Dahl.

12 S. Klimovski, R. Desoska, T. Karakamisheva, Constitutional Law, Skopje 2009, p. 344.

${ }_{13}$ M. Jovicic, Parliamentary System vs. Presidential and Parliamentary System, "Archive for Legal and Social Sciences” 1992, Belgrade, p. 29. 
and balances" 14 between the legislative, the executive, and the judicial powers. This system finds its original form in the United States, which today may be the only successful presidential system of governance. For the parliamentary system, the existence of a flexible division of power is characteristic and which is expressed by equality, cooperation and mutual influence between the legislative and the executive powers. This system was created in England, and consistency in its application is observed in both Japan and Italy. Today it appears in many varieties and shapes in countries such as Belgium, the Netherlands, Canada, India, and Germany. The parliamentary system is built on the unity of power, where the Parliament is the sole holder of the legislative process, with no other state body having the right to abolish or annul the laws and the highest acts. The Assembly elects, i.e., appoints the executive bodies that are then held accountable to it. This particular system of government exists today in Switzerland. Mixed systems are characterised by combined elements of the presidential and parliamentary systems. The most important feature in this system is the position of the head of state as the basic institution of the system. In addition, there is a flexible division of power and political responsibility of the government in the parliament. The mixed system has its roots in France, and its example was followed by Portugal, Russia, Poland, Ukraine, and other Eastern European countries.

\section{The Constitutional Legal Framework of the Model of Democracy in the Republic of Macedonia}

On November $17^{\text {th }}$, 1991, the Constitution of the Republic of Macedonia, which was preceded by the Declaration of a Sovereign and Independent State, was adopted. The precursor of the Constitution of the independent Republic of Macedonia were the constitutional amendments adopted in August 1990, which created a legal framework for starting the transition of the state from socialism to democracy and from the federal state of SFRY to an independent state. This Constitution, according to its conception, is among the liberal democratic constitutions that were adopted during the nineteenth century and, with certain changes, have continued to rule to this day in democratic countries. ${ }^{15}$ In the philosophy of this Constitution, the central value was the liberal democracy with a parliamentary form. At the same time, the Preamble of the Constitution starts from the historical fact and the historical and legal continuity of

${ }^{14}$ The principle "checks and balances" ensures that no authority is too powerful and each authority is limited in power.

15 S. Klimovski, R. Desoska, T. Karakamisheva, op. cit., p. 181. 
the Macedonian state as a national state of the Macedonian people, which ensures full civic equality and permanent coexistence of the Macedonian people with Albanian, Turkish, Vlach, and Roma people, along with other nationalities who live in the Republic of Macedonia.

In the period after becoming independent, the Republic of Macedonia faced many challenges as a new independent state that was created on the basis of the right to self-determination after the break-up of SFR Yugoslavia. After a proclamation of independence, the country began moving towards the development of a parliamentary democracy, where the freedom of political association was guaranteed for the first time, that is, the formation of several political parties as subjects in an election contest. The Assembly became unicameral, and instead of the collective presidency of the Republic of Macedonia, the position of President of the Republic was introduced. The Executive Council became a government, and the secretariats were renamed to ministries. ${ }^{16}$ This precisely was the establishment of the elements of the next parliamentary system. Set on the basis of the already well-built democracies, the Macedonian Constitution introduced a system of "checks and balances" with the separation of power into executive, legislative, and judicial powers. ${ }^{17}$

The relatively short-lived experience of Macedonian parliamentarism and democracy once again proves that the actual power and relations of the Macedonian institutions depend mostly on the constitutional norms but not only. During most of President Kiro Gligorov's mandate, the system of governance de facto functioned as presidential. ${ }^{18}$ President Gligorov's personality and social democratic parliamentary majority in the period of 1992-1998 enabled him to play the leading role in making important decisions.

With the Constitution of 1991, the Republic of Macedonia was defined as a sovereign, independent, democratic, and social state. The fundamental values of the constitutional order were provided through 11 basic principles. According to this, the socio-economic and political system is based on the principle of the rule of law, human freedoms and rights, the separation of power, the market economy and other fundamental values of a modern, democratic society. The adoption of this Constitution marked the beginning of the construction of a new social and political system, as well as a new political and economic strategy for the develop-

16 B. Vankovska, Political system of the Republic of Macedonia, Skopje 2014, p. 154.

17 T. Chokrevski, Redefinition of the Function of Law in Countries in Transition: the Case of the Republic of Macedonia, "Balkan Forum", no. 2/1996, p. 148.

18 G. Siljanovska Davkova, Modern "models" of organization of government: dilemmas and challenges, UDK 342.25/28, Izvorniznanstveni rad, 2010, p. 377. 
ment of the state. But has this Constitution passed the test of time? During its existence of 25 years (so far), the Constitution has been amended on seven occasions, and it currently has 32 amendments. Under pressure from the Republic of Greece, as well as the pretensions for membership in the United Nations, in 1992, two amendments were adopted that referred to the fact that Macedonia had no territorial pretensions towards other countries and that it would not interfere with the internal affairs of other countries.

The most dominant and dramatic changes came about in 2001, when the principles and rules of the Framework Agreement were embedded. Namely, 15 existing Articles were amended; those related mostly to the issues of using languages and alphabets, cultivating one's own ethnic identity, the use of symbols, the mechanisms of political decision making in the selection of important state functions and bodies, and the formation of separate parliamentary bodies. Primarily, an amendment to the constitutional preamble was made, which established the multi-ethnic character of the state. The amendment of 2004 provided constitutional protection of the freedom and inviolability of letters and all other forms of communication, and one could deviate from this right only by court decision. As a result of the efforts for Euro-Atlantic integration, reforms in the judiciary were carried out in 2005, i.e., the definition of courts, the election and dismissal of judges, the establishment of the judicial council and the guarantee of the right of appeal. In 2009, the presidential electoral threshold was reduced from $50 \%$ to $40 \%$, and, with the amendments in 2011, was provided the possibility of the extradition of Macedonian citizens on the basis of a ratified international agreement via court decision.

\section{The Political System in the Republic of Macedonia 2001 - Today}

The Republic of Macedonia was the only state that got through the breakup of Yugoslavia without suffering military conflict and bloodshed. However, since gaining independence, many domestic and international commentators have often warned of an imminent crisis or conflict in Macedonia. ${ }^{19}$ The inter-ethnic tension that has dragged on in the past escalated with an eight-month military conflict in 2001, which was the most critical point Macedonia faced after its independence. The conflict ended with the ratification of the Ohrid Framework Agreement (OFA) that established a framework for inter-ethnic coexistence and a Euro-

19 Separation of powers and implementation of the Ohrid Framework Agreement, Skopje 2008, p. 9. 
Atlantic view of the state. This agreement was, in principle, accepted by both sides of the conflict as the only alternative for Macedonia and its citizens. The solutions scheduled in the agreement, later embedded in the constitutional amendments, meant extending the rights of communities but also meant redesigning the political system. Crucial for post-conflict reconstruction is the conciliation of ethnic groups and the reintegration of the people. The success of this process is influenced by the separation of powers as well as the cooperation among the ethnic groups and their leaving the past behind.

It can be said that in the first decade of independence, ethnic Albanians were excluded from the decision-making process in the country. They were less represented in the public administration, and the use of the Albanian language in the Parliament and in higher education was banned. Instead, the power of the Albanian politicians was highly limited through the ministries, which was a particular trick to proving their legitimacy in front of the largest minority in Macedonia. ${ }^{20}$ Most of the concepts of democracy are based on the principle of the "rule of the people", but since 1991, when the first Constitution was adopted and, until 2001, almost no one disputed that "the people" primarily meant "the majority", that is, the ethnic Macedonians who comprised $64.2 \%$ of the population, unlike Albanians who accounted for $25.2 \%$ and other minorities including Turks, Roma, Vlachs, Serbs and Bosniaks. ${ }^{21}$ This was part of the reason behind the military conflict.

The aim of the Ohrid Agreement was not only to end military action and establish peace, but was also a treaty that the Macedonian Constitution set on a new basis. Namely, the agreement provided a series of constitutional changes that were adopted by the Macedonian Assembly in late 2001 and early 2002. Thus, the official language was considered to be the one spoken by more than $20 \%$ of the population, a double-majority system for the crucial areas of the legislation was introduced, which was composed of the majority of votes in the Assembly and of the majority of votes from the representatives of the minority, equitable representation in the public administration was also introduced and new reforms for decentralisation in Macedonia were anticipated.

In order to achieve equitable representation in the public administration and in the police forces, the political elites agreed on a system of

20 S. Ripiloski, S. Pendarovski, Macedonia and the Ohrid Framework Agreement: Framed Past, Elusive Future, "Perceptions", Summer 2013, vol. XVIII, no. 2, p. 136.

${ }_{21}$ M. Maleska, Multiethnic democracy in Macedonia: political analysis and emerging scenarios, "New Balkan Politics", issue 13/2013, p. 7. 
quotas based on ethnic lines. In the laws that regulate employment in the public administration, measures were implemented that would ensure an equitable representation of communities in all central and local public bodies and at all levels of employment in those bodies, while respecting the rules of competence and integrity according to which the public administration is managed.

After gaining independence in 1991, the Republic of Macedonia experienced a high degree of centralisation that had a negative impact on local development and imposed the need for an immediate start of the decentralisation process. The development of the decentralised government was also foreseen with the OFA through which the powers of the elected local representatives would be strengthened and their responsibilities would be significantly increased in accordance with the Constitution and the European Charter of Local Self-Government, reflecting the principle of vertical organisation, which is currently valid in the European Union. ${ }^{22}$ This move meant increasing the participation of the citizens in democratic life as well as ensuring greater respect for the identity of the communities. This gave greater autonomy to the communities with a predominantly Albanian population, provided greater inclusion of the non-dominant groups at the local level, and the map of the municipalities received territorial reorganisation. The process of decentralisation in the Republic of Macedonia began with the adoption of the Law on Local SelfGovernment, ${ }^{23}$ the Law on Local Self-Government Financing, ${ }^{24}$ the Law on the City of Skopje ${ }^{25}$ and, lastly, but very importantly, the Law on the Territorial Organisation of the Republic of Macedonia and Definition of Areas of Local Self-Government. ${ }^{26}$ The Law on Local Self-Government defines the responsibilities of the municipalities. According to this law, "the municipalities independently, within the framework of the law, regulate and perform activities of public interest with local importance, determined by this or other laws and are responsible for their performance."

The implementation of the decentralisation process in Macedonia started with the so-called "zero phase", i.e., the phase in which the minimum necessary financial management capacities were provided by the municipalities. Later there followed the first phase, which required the taking over of property and obligations in relation to the decentralised competencies as did the second phase in which the municipalities took

22 See: Ohrid Framework Agreement: paragraph 3.1.

23 "Official Gazette of RM", no. 5/02.

${ }^{24}$ Ibidem, no. 61/04.

25 Ibidem, no. 55/04.

${ }_{26}$ Ibidem, no. 55/04. 
decision-making powers regarding the functioning of budget users. Despite these reforms, the question arises as to whether local government can develop at the level of cultural autonomy along ethnic lines? If we were to analyse the adopted laws, we would likely come to the conclusion that it would be difficult to happen. First of all, the Constitution ${ }^{27}$ and the Law on Local Self-Government ${ }^{28}$ guarantee a single local government except for the City of Skopje, operating as a separate unit. Subsequently, the Law on Fiscal Decentralisation did not provide fully autonomous financing of the municipalities, and the Law on Territorial Organisation of the Local Self-Government did not start from the criteria for creating absolute ethnic municipalities. ${ }^{29}$

In the next few years after the signing of the OFA, there followed a completely new dynamic between the political elites. The new coalition government that was formed after the 2002 elections comprised of the SDSM and the Democratic Union for Integration (DUI) and had an Albanian Education Minister for the first time. ${ }^{30}$ This carried great symbolic significance for the Albanian population, whose issue of higher education being in the Albanian language was ignored. ${ }^{31}$ The SDSM and DUI had a common agenda for reforms in education, which they had negotiated even before the founding of the coalition that they followed over the subsequent four years. In this way, the government coalition partners had joint participation in the decision-making process, which is also indicated by the fact that a majority of Albanian MPs are needed to enact all laws related to education.

The parliamentary elections in 2006 brought forth a new course of events. In these elections an opposition that was led by VMRO-DPMNE (the Internal Macedonian Revolutionary Organization - Democratic Party of Macedonian National Unity) won, and which later formed a coalition government with the DPA (the Democratic Party of Albanians). From a legal point of view, this coalition was not illegal, but it was partially illegitimate, because the winner of the Albanian political camp was the DUI with 16 MPs, while the DPA had only 11 MPs. This actually caused a sense of injustice among the ranks of the DUI as they thought

27 Constitution of the Republic of Macedonia, Article 117.

${ }_{28}$ Law on Local Self-Government, Article 4.

29 See: Separation of powers and implementation of the Ohrid Framework Agreement, Friedrich Ebert Foundation, Skopje 2008, pp. 211-212.

${ }^{30}$ Azis Polozani was elected as Minister of education and science of the Republic of Macedonia, who performed this function from 1 November 2002 to 6 July 2006.

31 C. Koneska, Vetoes, Ethnic Bidding, Decentralisation: Post-Conflict Education in Macedonia, "Journal on Ethnopolitics and Minority Issues in Europe", vol. 11, no. $4 / 2012$, p. 40. 
that they should become part of the government. One of the most illustrative examples of the standstill in political dialogue in the Republic of Macedonia was the case of the so-called "May Agreement" in 2007. The background of this agreement was the OFA itself, which did not provide any specific provisions about the issue of which political factors should form the government after the parliamentary elections, although by 2006, the unwritten rule was that the winners in the two ethnic campuses in the country would do it. In 2007, the DUI MPs left the Assembly of the Republic of Macedonia as a sign of protest against the legislation passed by the Badinter principle, but without their votes. After that, the DUI immediately requested negotiations on an "inter-ethnic" level with the Government, as a prerequisite for their return to the Assembly. ${ }^{32}$ Although a formal agreement was never made available to the public, nor did its formal signing ever occur, the achievement of this agreement resulted in the return of all of the DUI MPs to the Parliament of the Republic of Macedonia on 30th May 2007 and the normalisation of the political dialogue and the situation in Republic of Macedonia. This was proved by the coalition between the VMRO-DPMNE and the DUI after the first early parliamentary elections in 2008.

Although some political experts believed that Macedonia had undergone the democratisation process ${ }^{33}$ by 2008, in 2012 the so-called "Black Monday" happened to the Assembly, that is, a crisis that arose during the adoption of the 2013 budget. Namely, the political dialogue within the framework of the commission debate faced a dead end in the moments when the opposition MPs submitted 1,200 amendments, stating that the budget was unproductive and full of spending that did not stimulate economic growth. After it became clear that the budget could not be passed under normal circumstances, the ruling VMRO-DPMNE used its position of being the majority in the Parliament to ignore all of the amendments of the opposition, while skipping the amendment debate and having a meeting in an emergency session about a new budget proposal. This move revolted opposition MPs, who boycotted the chamber even before the start of the session. They stated that they would stand in front of the Parliament of the Republic of Macedonia and that they would not allow a violation of the Constitution, the law, or the Rules of Procedure. This led to a reaction from security agents in that they physically removed the opposition MPs and the media from the Assembly Hall. The problem

${ }^{32}$ N. Markovic, M. Popovic, Political Dialogue, Skopje 2015, p. 26.

33 See: S. Levitsky, L. Way, Competitive Authoritarianism Hybrid Regimes after the Cold War, Harvard 2010, p. 127. 
itself was solved by the formation of a committee on the proposal of the President of the Republic of Macedonia, which included two representatives of the opposition and the government, and chaired by the Dean of the Faculty of Law in Skopje. After a long session, the Commission drew up a report that was subsequently submitted to and accepted by the Assembly of the Republic of Macedonia. This event blocked Macedonia's progress towards EU membership. The latest political crisis in the Republic of Macedonia took place after the early parliamentary elections in 2014, where the coalition led by VMRO-DPMNE won again. After the elections, opposition party SDSM boycotted the Assembly of the Republic of Macedonia stating that the elections had been unfair and undemocratic and passed numerous remarks on the election process. However, after the boycott, the leaders of the two largest parties in the Republic of Macedonia, SDSM and VMRO-DPMNE, tried to negotiate the return of SDSM to the front bench, but these negotiations were unsuccessful. ${ }^{34}$ This event was a major challenge for Macedonia's parliamentary democracy.

Such events overshadowed the stability of the Assembly as a forum for interparty dialogue. In the absence of an opposition, a question arose: Can an Assembly of that composition pass quality laws? In a sound, democratic system, the function of the opposition may be of the utmost importance, because it has the role of a "check" that is aimed at stopping the making of bad decisions in the legislature. From the recent crises in the political life of the Republic of Macedonia, we can conclude that the government and the opposition have never been in such a tense and hostile relationship. Constant mutual accusations, non-deviation of requests, as well as the refusal of a common compromise, lead us to the conclusion that the political scene in Macedonia has turned into a military front. The real test that Macedonia's democracy is faced with is whether both sides are fighting for personal interests or for the interests of the people.

\section{Elements of Consociational Democracy in North Macedonia - Issues, Challenges and Experiences}

Considering the differences and fragmentation of the Macedonian society, one can conclude that Macedonia does not naturally gravitate towards a system of parliamentary democracy. Instead, a political system is needed that will correspond to a deeply divided society such as that of Macedonia's. Such political systems are based on the principles of consensual or consociational democracy, where the majority that decides reflects the

${ }^{34}$ N. Markovic, M. Popovic, op. cit., p. 29. 
more dimensional differences that are prevailing in society. Parliamentary democracy guarantees effectiveness, but in fragmented societies, consensus democracy is needed for stability.

Consociational democracy is characterised by four features: (1) A great coalition of political leaders of all of the more important segments of a certain pluralistic society is in power; (2) Mutual veto or principle of the majority of like-minded individuals that functions as an additional protection of vital minority interests; (3) Proportionality as a basic measure in determining political representation when appointing civil servants and allocating public funds; and (4) A high degree of independence of the segments in solving internal issues. ${ }^{35}$ The main characteristic of the great coalition is the association and mutual agreement of political leaders, who then jointly participate in the management of plural societies. The power of veto maintains a balance because it allows for the protection of minority groups from being outvoted. The principle of proportionality is an important element when it comes to decision making because it is an unbiased measure through which the more important functions are assigned to different segments. The independence of the segments is an element that increases their autonomy because it gives them the opportunity to decide on issues that are at the level of a particular minority. This means that issues of common interest are resolved jointly, and all other issues are left to the segments.

Consociational democracy corresponds mostly to small countries, that is, to countries that are located on small territories and have small populations.

In fact, this is proven by the example of the countries in which this model of democracy was established. The basic reason lies in the fact that a small territory reinforces the spirit of cooperation and agreement between the political elites. Namely, in such conditions, the decision-making process is much simpler because the political elites know each other well and are more likely to have a face-to-face encounter. In addition, small countries have limited international power, feel more threatened than the great powers, and therefore refrain from active foreign policy and strive to maintain and strengthen internal stability. However, this model of democracy can exist in those pluralist and multi-ethnic societies, provided that the majority of the minority group allows it an active role in the overall political life of the state especially.

As favourable factors that influence the establishment and maintenance of consociational democracy, Arend Lijphart lists several condi-

${ }^{35}$ S. Klimovski, T. Karakamisheva, R. Deskoska, op. cit., p. 142. 
tions including: the balance of power between segments; a small territory of the concerned country; separation of segments; tradition in concluding agreements between elites; comprehensive loyalty; the existence of crossed gaps and the like. ${ }^{36}$ These elements, as he points out, should not be required nor necessary to create conditions for a consociational democracy, since they can also be part of non-consociational democracies just as they may be absent in consociational democracies. But the more elements are present, the better the chances for the stability of democracy in a pluralist society.

Lijphart's approach to democracy in divided societies is at the centre of many post-conflict institutional arrangements in recent decades, including Macedonia, which, since 2001, has introduced some of the main principles of separation of powers. ${ }^{37}$ In fact, we can notice the traces of consociation in the period up to 2001, for example, through the great ruling coalition, i.e., the automatic participation in the power of an Albanian party, regardless of the election results. The existence of special quotas and other appropriate measures was part of the government's programme of just representation of non-majority communities through positive discrimination. Although decentralisation was foreseen with the OFA, the local self-government persisted beforehand. By concluding the Framework Agreement, the political system in the Republic of Macedonia was redesigned, which resulted in the crystallisation of the elements of consociational democracy. Although the great coalition was not provided by the Constitution, it became a tradition since the first elections in independent Macedonia. This is due to several factors. Fistly a coalition government was an inevitability because of the proportional election model and fragmentation in the political system.

The formation of a majority government is almost impossible, so the forming of coalition governments became the rule. In addition, the implementation of the executive power is always easier if there is support from the smaller joint parties. Furthermore, after the signing of the OFA, a mechanism for the protection of minority communities in Macedonia was provided, through the veto power, i.e., the so-called Badinter principle. To avoid any discrimination of these communities, they have a veto power that allows them to control the decision-making process for which they have a particular interest. In such situations, the required number of

${ }^{36}$ M.P. Schendelen, C. M. Consociational, Democracy: The Views of Arend Lijphart and Collected Criticisms, "The Political Science Reviewer", no. 15/1985, pp. 143-184, https://politicalsciencereviewer.wisc.edu/index.php/psr/article/view/21.

37 C. Koneska, Vetoes, Ethnic Bidding, Decentralisation: Post-Conflict Education in Macedonia, "Journal on Ethnopolitics and Minority Issues in Europe", vol. 11, no. 4/2012. 
votes must be provided by the present members of the minority communities. Equitable representation of the members of the communities was raised at the level of the fundamental value of the constitutional order. The proportionality was set as the basic standard in political representation, in the distribution of public funds as well as employment in the public sector, especially in sectors such as education and internal affairs. However, in practice, this principle began to be achieved through the adoption of mechanical solutions where ethnicity played a greater role than expertise, education, and experience. This put democracy in question and clashed with the principle of non-discrimination. The autonomy of the segments was ensured through the decentralisation process that began after 2001. This was achieved through the transfer of certain competencies and finance from the central to the local government, as well as greater participation of the citizens at a local level. It is important to note that this process also developed an ethnic dimension, since not only a two-thirds majority, but also a double majority was provided for decision making on issues related to local self-government. The proportional electoral model was applied for the first time after electoral reforms in 2002. Although this model was not provided by the OFA, it was assumed that its application would create preconditions for a successful consociational democracy in the country.

However, there are several elements of a consociational democracy that Macedonian society lacks. Before the formal ratification of the OFA, some experts desperately tried to explain why the famous "Lijphart Recipe" would not properly function in a binationally divided state such as Macedonia. ${ }^{38}$ The first and most important element is the balance of the power of the segments. Thus, in the foreground, the two largest communities are included, i.e., the Macedonian and Albanian communities, while the rest are left out of political arrangements. We can notice that smaller communities are taken into account only in cases where a double majority cannot be secured. Furthermore, even though political pluralism became a fixture of the Macedonian political scene after independence had been secured, we can freely say that ethnic division resulted in the creation of two political (i.e., ethical) blocs. Despite that, there is no balance of power between the executive and legislative powers, as the Government dominates over the Parliament in political processes. The Assembly over the past period of more than two decades, instead of becoming a controlling

${ }_{38}$ B. Vankovska, The Procrustean Bed of the State Building in the Republic of Macedonia (1991-2011), in: The Macedonian Question: 20 Years of Political Struggle into European Integration Structures, eds. Z. Daskalovski, M. Risteska, Libertas, Rangendingen 2012, p. 14. 
body, has become a body strictly controlled by the government. ${ }^{39}$ This is partly due to the fact that about $90 \%$ of the draft bills come from the government, which is partly a result of the weak position of parliamentary committees. As for the second holder of the executive power - the president does not have powerful mechanisms for controlling the Assembly, and his veto power can be easily rejected. If we look at the case with other countries where consensus democracy has been established, we will notice that the legislative body has a strong independent position compared to other government structures, but de facto it is not so. For example, the Swiss Constitution explicitly gives a powerful and independent position to the federal assembly, but really the power of the legislature is selective.

From the abovementioned, we can conclude that the political system in the Republic of Macedonia is moving in the direction of a consociational democracy, but it still deviates from the Lijphart's model in certain criteria. If the first decade of independence was about the parliamentary system, post military conflict the Macedonian system gained strong elements of power sharing, that is, of a consociational democracy, through the Framework Agreement and constitutional amendments. The shape of governance is constantly evolving, developing and changing and for this reason, this issue remains open to debate. As the situation on Macedonian soil has changed in the past 25 years, the political system itself has taken its own form, adapting itself to the newly emerging situation. However, I believe that we are yet to learn what kind of model is best for Macedonia as a heterogeneous society composed of different ethnic, linguistic, cultural, and religious groups.

\section{Conclusions}

The political system in the North Macedonia, both from a normative point of view and from a realistic point of view, is a result of the mutual influence of several factors that determine its essence. At different periods of time, these factors played greater or lesser roles, but the final result was a reflection of their overall impact. The first Macedonian Constitution in practice adopted a radical systemic change as a result of the changed international and domestic social and political environment. The need to create a new constitutional framework also appeared on Macedonian soil, due to the transition from socialist one-party systems to democracy. The Constitution has undergone many changes in the form of numerous

39 N. Ambarkov, The Republic of Macedonia, Consociational (consensual) enough?, "Iustinianus Primus Law Review", vol. 5:1, p. 6. 
amendments that followed the transformation of the modern Macedonian state. The 2001 armed conflict resulted in the creation of a new relation of relationships in Macedonian society in which multiethnicity and the civic concept require a compromise that is most easily achieved by the application of the most characteristic elements of the model of consociational democracy.

The construction of power took place through elections, but the electoral model changed several times, starting from the majority, through one combined, to a proportional one. This consensus characteristic was aimed at reflecting the ethnic and religious diversity of Macedonian society.

The flexible separation of powers as a feature of the parliamentary system can be seen in the mutual control of the three powers. Thus, the Assembly controls the executive power through the parliamentary questions, as it does interpellation, votes of no-confidence of the Government, the election and dismissal of the President and members of the Government, the right to ask the President of the Republic for an opinion on issues within his jurisdiction as well as through the right to raise an impeachment for the President of the Republic in case of any violation of the Constitution and laws. The Assembly affects the judiciary mainly through the adoption of the Law on the Courts which determines the type and number of courts, and further still by determining the court budget, and also through the election of a public prosecutor and the election of three out of fifteen members of the Judicial Council. The Government enters the legislative branch by proposing the budget, proposing laws, giving a mandatory opinion on draft bills, participating in the work of the Assembly, and by the right to request a session. The President, on the other hand, influences the legislative power through the suspensive veto power of laws that are adopted with a relative or absolute majority, in addition to leading the appointment and dismissal of the Government and the appointment and dismissal of officials during military emergencies and state of emergency.

From this we can conclude that the Macedonian system is a hybrid model in which the elements of parliamentary and consociational democracy are combined. Leaving liberal democracy, the Macedonian system of regulation was moving towards a power-sharing model which, in postconflict societies, is supported above all by the international community as an optimal solution to the demands for secession and the right to selfdetermination. The separation of powers does not mean that institutions share their tasks and then act without consulting and cooperating with each other. On the contrary; the power-sharing model indicates that each 
authority consults with others in the decision-making process. We have noted the basic principles that apply to this concept through the development of the decentralised government, non-discrimination and equitable representation in the public administration, as well as confidencebuilding measures to overcome the consequences of the 2001 conflict. However, the most important element was the double-majority system, which requires the agreement of the minorities that are represented in Parliament to make crucial decisions. This system was originally proposed by Robert Badinter, former president of the French Constitutional Court, who was involved in the drafting of the Ohrid Agreement in July 2001. The purpose of this principle was to link the ethnic communities to the national legislative body for making decisions that are of particular importance to minority communities. The advantage of "Badinter's Principle" was that with such relatively restrictive regulation, the danger of the majority group's domination of decisions that have a direct impact on minorities was limited. On the other hand, it has brought the danger that the majority can still impose its will on issues that do not require a double majority. Although this principle was well thought out for a post-conflict society like Macedonia's, some analysts believe that it fails when dealing with the equitable representation of minority communities. ${ }^{40}$ Namely, the Albanian minority had the loudest voice when making these decisions, while the rest were neglected. As for the other principles of the separation of powers, in the sensitive areas of public administration, especially the police, the number of Albanians employed in the civil services and state administration remained low during the 1990s. Thus, public administration reform was considered crucial and aimed at strengthening the sense of belonging to the state. Before the Ohrid Agreement, only 7\% of public administration employees were Albanians, and the representation of other minorities, such as the Turks and Roma, was also very low. The reasons for this phenomenon were multiple and cannot be reduced only to a matter of discrimination. However, it is a fact that nationality played a role, and for this reason Albanians primarily sought employment in the private sector. With the OFA, this picture has changed drastically. Thus, the representation of $2.5 \%$ of Albanians in the Ministry of Interior as of 2001 rose to more than $10 \%$ in the first half of 2003. Other state institutions followed suit. Also, although the Army was excluded from the reforms for just representation, it received many more Albanians in its ranks.

40 F. Bieber, Partial Implementation, Partial Success: The Case of Macedonia, 2005, in: Power Sharing: New Challenges For Divided Societies, eds. D. Russell, I. O'Flynn, London 2005, pp. 107-122. 
According to the political analyst Florian Bieber, the principle of separation of powers existed in Macedonia before the military conflict, but with the signing of the Ohrid Framework Agreement, it only got a formal character ${ }^{41}$ The Republic of Macedonia is still a young democracy that makes continuous efforts to adjust its system to the current circumstances in Macedonian society. So far, the Constitution has been flexible enough to accommodate the major changes that have been happening both politically and socially. The real test is whether it will be strong enough to maintain the basic principles, thereby providing a stable system.

\section{References}

Ambarkov N., The Republic of Macedonia, Consociational (consensual) enough?, "Iustinianus Primus Law Review", vol. 5:1/2017.

Berglund S., et al., The Handbook of Political Change in Eastern Europe, Edwar Elgar Pub., Cheltenham 2013, DOI: https://doi. org/10.4337/9781782545880.

Bieber F., Partial Implementation, Partial Success: The Case of Macedonia, 2005, in: Power Sharing: New Challenges For Divided Societies, eds. D. Russell, I. O'Flynn, Pluto Press, London 2005.

Chokrevski T., Redefinition of the Function of Law in Transition Countries: The Case of the Republic of Macedonia, "Balkan Forum", no. 2/1996.

Schendelen M.P., Consociational C. M., Democracy: The Views of Arend Lijphart and Collected Criticisms, "The Political Science Reviewer", no. 15/1985, https://politicalsciencereviewer.wisc.edu/index.php/psr/article/view/21.

Dahl R., Dilemmas of Pluralist Democracy, Yale University Press, New Haven 1982.

Dahl R., On Democracy, Yale University Press, London 1998.

Division of power and implementation of the Ohrid Framework Agreement, Friedrich Ebert Foundation, Skopje 2008.

Handbook for parliamentary elections in the Republic of Macedonia, Konrad Adenauer Stiftung, Institute for Democracy, Skopje 2014.

Holliday H., From Ethnic Privileging to Power-Sharing: Ethnic Dominance and Democracy in Macedonia, in: The Fate of Ethnic Democracy in Post-Communist Europe, eds. S. Smooha, P. Järve, LGI-ECMI, Budapest 2005.

Jovicic M., Parliamentary System vs. Presidential and Parliamentary System, Archive for Legal and Social Sciences, Belgrade 1992.

Klimovski S., Desoska R., Karakamisheva T., Constitutional Law, Skopje 2009.

41 Ibidem. 
Klimovski S., Karakamisheva T., Desoska R., Political System, Skopje 2010.

Koneska C., Vetoes, Ethnic Bidding, Decentralization: Post-Conflict Education in Macedonia, "Journal on Ethnopolitics and Minority Issues in Europe", vol. 11, no. 4/2012.

Levitsky S., Way L., Competitive Authoritarianism Hybrid Regimes after the Cold War, Cambridge University Press, Harvard 2010, DOI: https:// doi.org/10.1017/CBO9780511781353.

Maleska M., Multiethnic democracy in Macedonia: political analysis and emerging scenarios, "New Balkan Politics", issue 13/2013.

Markovic N., Popovic M., Political Dialogue, Konrad Adenauer Stiftung, Institute for Democracy, Skopje 2015.

Mojanoski C., Chronicle of the Macedonian Democracy, Skopje 2009.

Ripiloski S., Pendarovski S., Macedonia and the Ohrid Framework Agreement: Framed Past, Elusive Future, "Perceptions", Summer 2013, vol. XVIII, no. 2.

Siljanovska Davkova G., Contemporary "models" of the organization of power: dilemmas and challenges, UDK 342.25/28, Original scientific paper, 2010.

Siljanovska-Davkova G., The Particularity of Democratic Transition of New States in the Western Balkans: The Case of Former Yugoslav Republics, in: Key Developments in Constitutionalism and Constitutional Law, ed. L. Basta, T. Marinkovic, ELEVEN, Hague 2014.

The former Yugoslav Republic of Macedonia, Presidential elections 31 October and 14 November 1999, Office for Democratic Institutions and Human Rights 1999.

Vankovska B., The Procrustean Bed of the State Building in the Republic of Macedonia (1991-2011), in: The Macedonian Question: 20 Years of Political Struggle into European Integration Structures, eds. Z. Daskalovski, M. Risteska, Libertas, Rangendingen 2012. 